Received: 2019/06/03, Revised: 2019/08/02, Accepted: 2019/08/05, Published: 2019/09/30 @2019 Nana Chung et al.; License Joumal of Exercise Nutrition and Biochemistry. This is an open access article distributed under the terms of the creative commons attribution license (http://creativecommons.org/licenses/by/2.0), which permits unrestricted use, distribution, and reproduction in any medium, provided the orginal work is properly cited. ${ }^{*}$ Corresponding author : Kiwon Lim Ph. D.

Department of Physical Education, Konkuk University, Seoul, Republic of Korea.

Phone: 82-2-450-3827

E-mail: exercise@konkuk.ac.kr

@2019 The Korean Society for Exercise Nutrition

\section{Influence of high fat and different types of carbohydrate diet on energy metabolism in growing mice}

\author{
Nana Chung ${ }^{1} /$ Kiwon Lim$^{2 *}$ \\ 1. Department of Physical Education, Sang-ji University, Wonju, Republic of Korea \\ 2. Department of Physical Education, Konkuk University, Seoul, Republic of Korea
}

[Purpose] The purpose of this study was to determine whether different types of carbohydrate diets with or without exercise changes energy metabolism at rest and during exercise.

[Methods] To minimize differences in food and energy intake between experimental groups, mice were pairfed. After 1 week of adaptation, 40 male ICR mice (6 weeks old) were randomly divided into four groups: Sta. (high fat + high starch). Scu. (high fat + high sucrose), StaEX. (high fat + high starch + exercise), and SucEX. (high fat + high sucrose + exercise). StaEX. and ScuEX. groups underwent training by running on a treadmill five times a week. After 10 weeks of training, energy metabolism was measured for $24 \mathrm{~h}$ and during a $1 \mathrm{~h}$ exercise period.

[Results] The final body weight showed no significant difference between the groups. However, the weight of abdominal tissues (epididymal, perirenal, and mesenteric adipose tissue) in training groups was markedly decreased following 10 weeks of training. Results of all energy metabolism $(24 \mathrm{~h}$ at rest and during $1 \mathrm{~h}$ of exercise) showed no significant interactions between diet and exercise. A brief summary of the results of the energy metabolism is that the metabolism related indicators over $24 \mathrm{~h}$ were more affected by the dietary pattern than the exercise but during the $1 \mathrm{~h}$ of exercise, training had more effect on energy metabolism than diet.

[Conclusion] Our findings confirm that: (a) the type of carbohydrates included in the diet influence the metabolic responses over $24 \mathrm{~h}$, (b) training had more effect on energy metabolism than diet during $1 \mathrm{~h}$ of exercise, (c) both results; abdominal adipose tissue weight and fat oxidation during exercise are suggestive for a beneficial effect of moderate physical activity on weight maintenance.

[Key words] High fat-high sucrose; High fat-high starch; Exercise; Energy metabolism

\section{INTRODUCTION}

Child obesity has become a significant health issue in Korea. Along with the adaptation to a Western diet over the past decades, the dietary patterns of the Korean population, especially Korean children and adolescents, have gradually been changing. The Western diet includes not only a diet high in processed or fast foods, but also physical inactivity ${ }^{1}$. Nowadays, many children spend a great deal of time being inactive. According to statistics, the average child spends approximately 4 hours each day watching television ${ }^{2}$. In addition, they spend most of their spare time playing video or computer games and cellphone. This can further increase the physical inactivity in children. The other characteristic of a Western diet is the high dietary lipid and sugar content present in processed foods ${ }^{3}$. Although the impact of specific macronutrients on health is highly debated, it is evident that diets rich in fat and carbohydrates, with or without exercise, result in obesity. Because of their palatability and higher energy density than that of other macronutrients, high fat diets may lead to excessive energy intake and cumulative positive fat balance. Moreover, because of the lower dietary induced thermogenesis, high fat diets may also decrease energy expenditure ${ }^{4,5}$. There is no apparent autoregulation between fat intake and fat oxidation. Fat oxidation levels are changed by the intake of other macronutrients ${ }^{6}$. On the other hand, carbohydrate oxidation shows strong autoregulation with carbohydrate intake because the capacity of glycogen storage is limited. The diet-induced thermogenesis associated with high carbohydrate diets would be higher than that associated with high fat diets because of glycogen storage and glucose stimulation of the sympathetic nervous system ${ }^{7-10}$. The types of carbohydrate may also influence metabolic responses such as thermogenesis and substrate utilization because the nutritional properties of carbohydrates depend on their rate and extent of digestion and absorption in the small intestine $e^{11}$.

In this study, we used two types of carbohydrates, sucrose and starch. Sucrose, the scientific name for sugar, is a disaccharide, which 
is a combination of two monosaccharides ${ }^{12}$. Sucrose is often combined with other sugars in foods such as sweets and beverages. It can also be hidden in many processed foods. Starches, sometimes called complex carbohydrates, are polysaccharides found in rice, the staple food of Koreans, as well as breads, potatoes, and corn. Hence, the body has to first break down the links between each sugar subunit in order to use the energy of the sugar molecules in the starch. This causes rapid increases in blood sugar levels, which stimulates the release of a large amount of insulin. Insulin draws sugar into the cells to be stored as glycogen, leading to a subsequent drop in blood sugar, which often leads to further consumption of carbohydrates. This phenomenon is called 'blood sugar roller-coaster' ${ }^{\prime 11}$. This triggers insulin resistance, where the cells become fatigued from constant high insulin signaling and no longer respond adequately to its release. Poor blood sugar regulation also stimulates the release of stress hormones, such as cortisol, which can contribute to weight gain as well as hypoglycemia ${ }^{13}$. In this sense, sucrose and starch may also have different effects on energy metabolism.

Although there is increasing interest in understanding the relationships between different types of dietary carbohydrates and appetite regulation, energy metabolism, body weight, and body composition, little is known about the impact of the consumption of different types of carbohydrates on metabolic responses, at rest and during exercise, in childhood. Most previous studies have focused only on the effects of $\operatorname{diet}^{14-17}$ and exercise ${ }^{18-20}$ on the changes in energy metabolism at rest and during exercise. There is limited information on the effects of simultaneous consumption of high fat and different types of carbohydrates (sucrose or starch), with or without exercise, on body weight, fat accumulation, and energy metabolism. Hence, the purpose of this investigation was to study the change in the fuels oxidized at rest and during exercise on a high fat-high sucrose and high fat-high starch diet, with or without exercise, in growing mice as one possible method to address child obesity.

\section{METHODS}

\section{Animals and treatments}

Prospective clinical studies on a high fat-high sucrose diet would be unethical because of the known detrimental metabolic consequences of this diet in humans. Therefore, we employed an animal model to examine the effect of a high-fat diet combined with different types of carbohydrates on energy metabolism. Five-week-old male ICR mice $(n=40)$ were purchased from Orient Rio Company (Seongnam, Korea). All mice were kept in a specific pathogen-free (SPF) environment (humidity; $50 \%$ and temperature $23 \pm 1{ }^{\circ} \mathrm{C}$ ) and housed in conventional cages ( $\mathrm{n}=5$ per cage) under a standard $12 \mathrm{~h}$ light/dark cycle Food intake and body weight were measured daily for 10 weeks.

\section{Experimental design}

During the one-week adaptation period, general clinical symptoms were observed and mice were selected and randomized according to the weight range. After adaptation, mice (6 weeks old) were randomly divided into four groups: Sta. (high fat + high starch), Scu. (high fat + high sucrose), StaEX. (high fat + high starch + exercise), and SucEX. (high fat + high sucrose + exercise). StaEX. and ScuEX. groups underwent training by running on a treadmill five times a week. After 10 weeks of training, energy metabolism was measured for $24 \mathrm{~h}$ at rest and during $1 \mathrm{~h}$ of exercise.

All experimental procedures were approved by the Animal Experiment Research Center of Konkuk University and Ethics Committee of the Konkuk University Institutional Animal Care and Use Committee (Permit Number: KU17114).

\section{Composition of the diets}

We designed studies to test the metabolic flexibility of mice to adapt to high fat and high sucrose or high starch diets through changes in substrate utilization. To clarify the influence of different types of carbohydrates on energy metabolism, mice were fed a high sucrose or a high starch diet containing identical amounts of proteins and lipids. Diets were matched for macronutrient and micronutrient content and the energy content of the two diets was identical (Table. 1). To minimize differences in food and energy intake between experimental groups, mice were pair-fed and the high fat-high starch diet was served as a baseline.

Table 1. Composition of the diets

\begin{tabular}{|c|c|c|c|c|}
\hline & HF+Hsta gm $\%$ & kcal\% & HF+Hscu gm $\%$ & kcal\% \\
\hline Corn starch & 40 & 39 & 5 & 39 \\
\hline Sucrose & 5 & & 40 & \\
\hline Casein & 24 & 21 & 24 & 21 \\
\hline Corn oil & 21 & 40 & 21 & 40 \\
\hline Total & 90 & 100 & 90 & 100 \\
\hline Density $(k c a l / g)$ & 4.7 & & 4.7 & \\
\hline Vitamin mix. & 1 & & 1 & \\
\hline Mineral mix. & 4 & & 4 & \\
\hline Cellulose & 5 & & 5 & \\
\hline
\end{tabular}

\section{Training method}

The exercise group used a treadmill for small animals. All mice in exercise groups $(n=20)$ were first introduced to running for 3 days. The mice were then trained five times per week for 10 weeks by gradually ramping up the speed and time under the following training conditions: 15 $\mathrm{m} / \mathrm{min}$, $8^{\circ}$ slope, $50 \mathrm{~min} /$ day for the first two weeks, then ramped up to $25 \mathrm{~m} / \mathrm{min}, 8^{\circ}$ slope, $60 \mathrm{~min} /$ day, at approximately $70-75 \%$ of the maximum oxygen uptake for the last four weeks. ${ }^{21-24}$

Details of the experimental group design and training program are shown in Figure. 1. To keep the mice running, the grid at the back of the treadmill delivered a mild electric foot shock. Mice in the sedentary group $(n=20)$ remained in their cages for the duration of the 10 -week training program. 


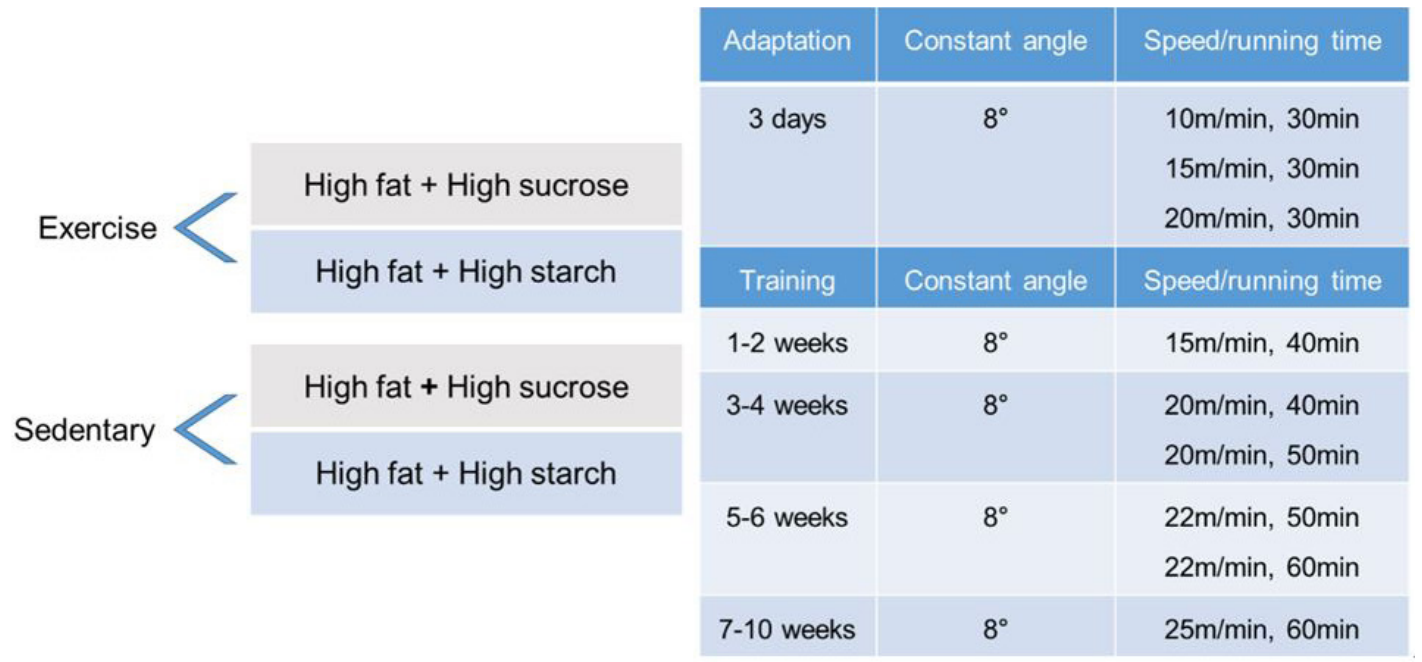

Figure 1. Experimental group design and training program.
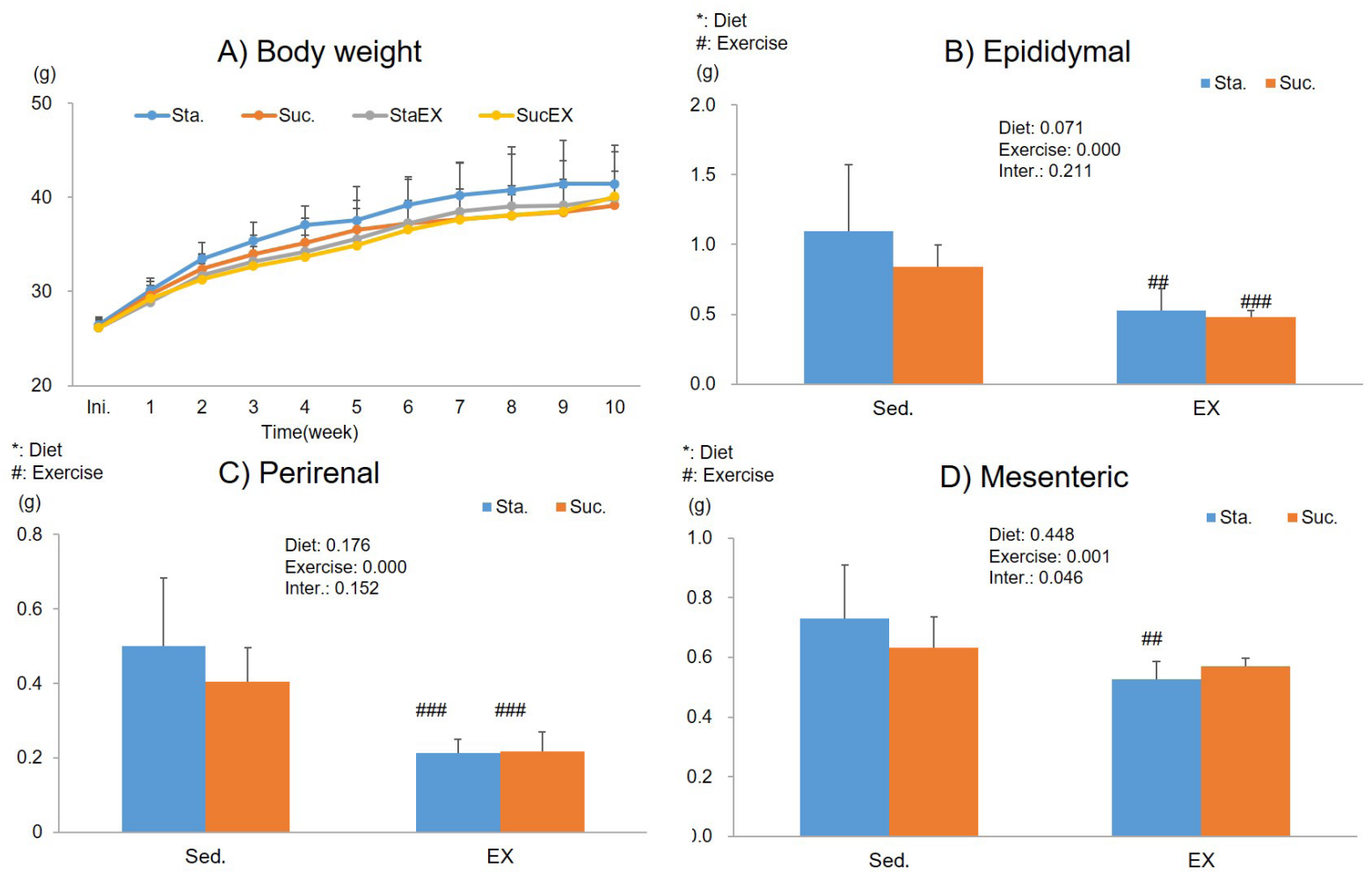

Figure 2. Influence of a high fat and different types of carbohydrate diet or/and exercise on body weight and abdominal adipose tissue weight. (A) Body weight (B) Epididymal adipose tissue weight (C) Perirenal adipose tissue weight (D) Mesenteric adipose tissue weight. Data are presented as means \pm SE ( $n=10$ per group). Values in the same row not sharing the same superscript differ significantly $\left({ }^{\#} P\right.$ $\left.<0.05,{ }^{\# \prime} \mathrm{P}<0.01,{ }^{\ldots \prime \prime} \mathrm{P}<0.001\right)$.

\section{Resting metabolic rate (RMR) analysis}

One week before the end of the experiment, the RMR was measured by indirect calorimetry, using an open-circuit device based on methods reported in previous studies $^{25,26}$ for $24 \mathrm{~h}$ stabilization. Two hours before the start of the measurement, the mice were placed in a metabolic chamber with a volume of approximately $1 \mathrm{~L}$ to reduce stress. ${ }^{26,27}$ The flow rate was kept constant at $1.2 \mathrm{~L} / \mathrm{min}^{26}$. During measurement, data were recorded for each diet ac- cording to their group and water was freely available.

\section{Energy metabolism alterations during exercise}

After 10 weeks of training, energy metabolism was measured for $1 \mathrm{~h}$ using exercise metabolism chambers ${ }^{23,28}$ under the training conditions of $18 \mathrm{~m} / \mathrm{min}, 8^{\circ}$ slope, and $50-55 \%$ of maximal oxygen uptake. Mice were placed in exercise metabolism chambers for adaptation $2 \mathrm{~h}$ before the measurement. 
A) Changes in oxygen uptake $\left(\mathrm{O}_{2}\right)$ over $24 \mathrm{~h}$

(m//kg/30min)

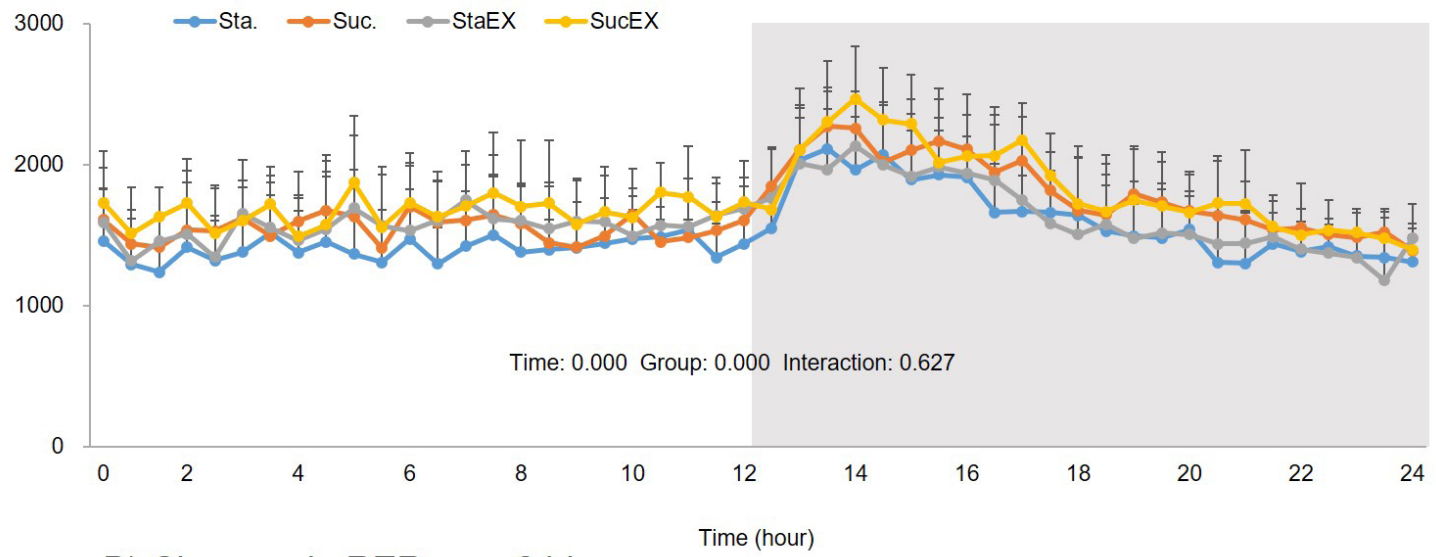

B) Changes in RER over $24 \mathrm{~h}$

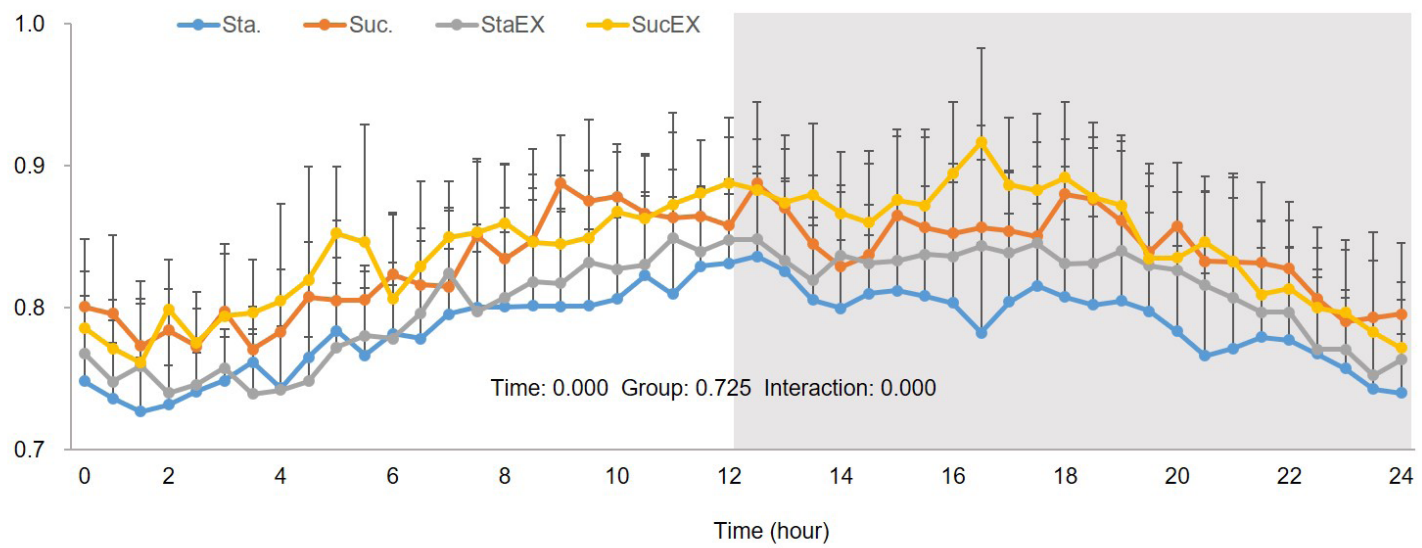

C) Sum of $\mathrm{O}_{2}$ uptake over $24 \mathrm{~h}$

$$
\text { *: Diet }
$$

\#: Exercise

$(\mathrm{L} / \mathrm{kg} / 24 \mathrm{~h})$

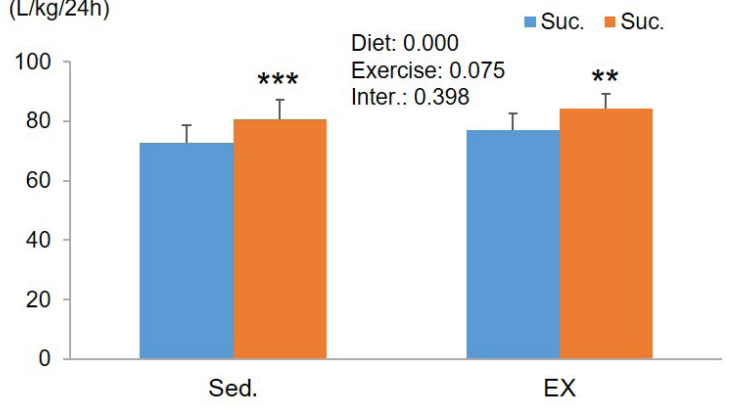

D) Average of RER over $24 \mathrm{~h}$

$$
\text { *: Diet }
$$

\#: Exercise

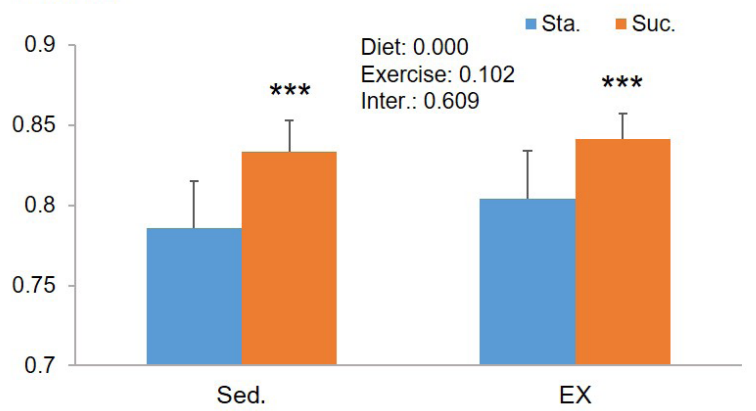

Figure 3. Influence of a high fat diet with different types of carbohydrates and/or exercise on oxygen uptake and respiratory changes ratio (RER) over $24 \mathrm{~h}$. A) Changes in oxygen uptake over $24 \mathrm{~h}$. B) Changes in RER over $24 \mathrm{~h}$. C) Sum of oxygen uptake over $24 \mathrm{~h}$. D) Average of RER over $24 \mathrm{~h}$. Data are presented as means \pm SE ( $n=10$ per group). Values in the same row not sharing the same superscript differ significantly $\left({ }^{*} \mathrm{P}<0.05,{ }^{* *} \mathrm{P}<0.01,{ }^{* * *} \mathrm{P}<0.001\right)$. 
A) Changes in fat oxidation over $24 \mathrm{~h}$

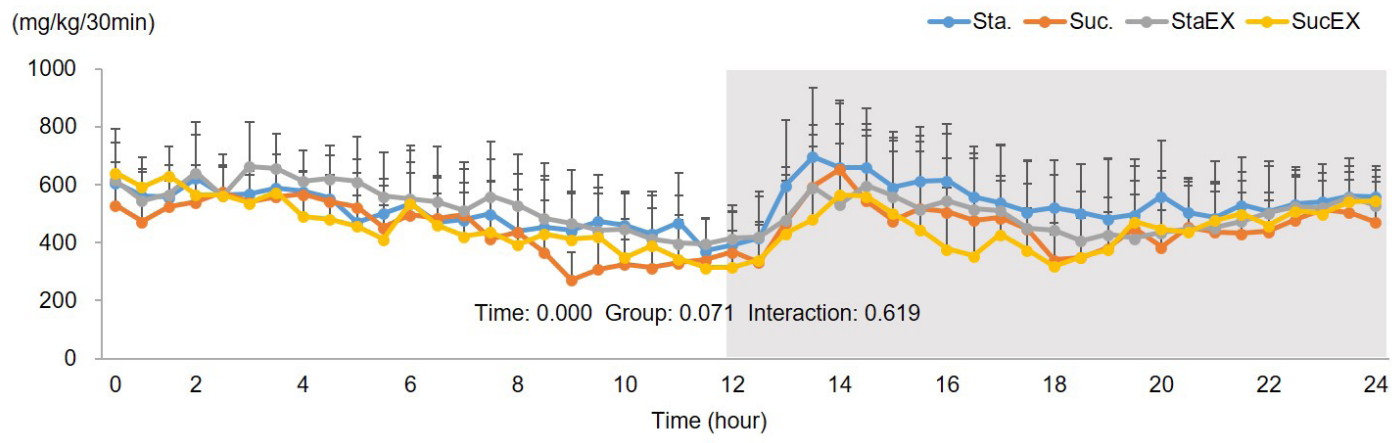

B) Changes in carbohydrate oxidation over $24 \mathrm{~h}$

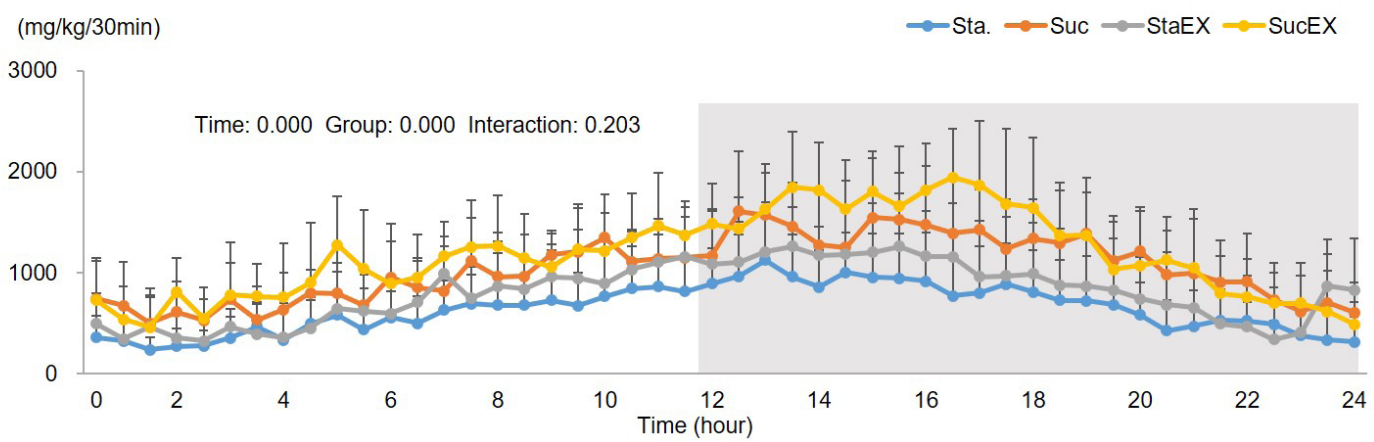

C) Changes in energy expenditure over $24 \mathrm{~h}$.

(cal/kg/30min)

$\leadsto$ Sta. $\leadsto$ Scu. $\leadsto$ StaEX $\leadsto$ ScuEX
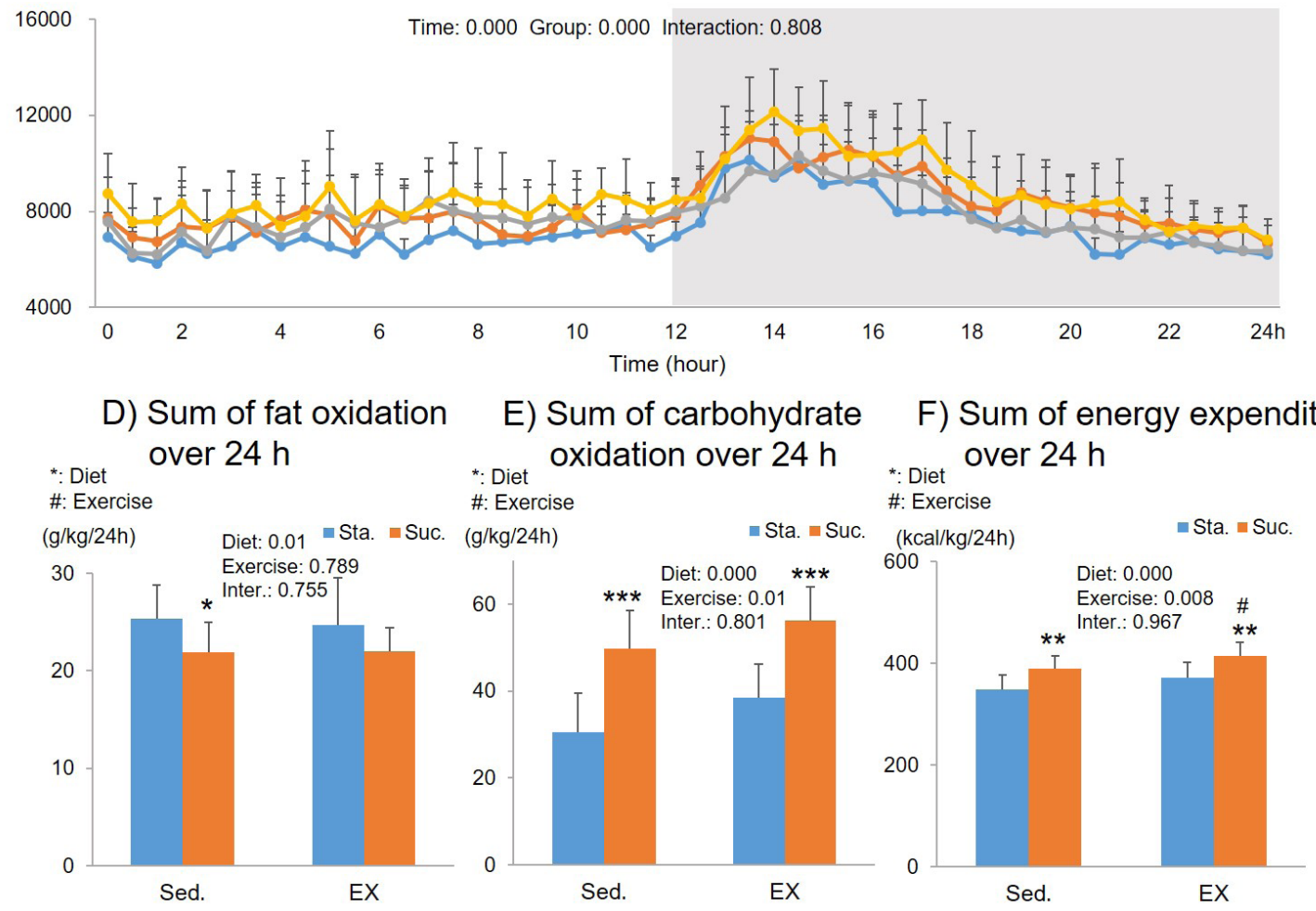

Figure 4. Influence of a high fat diet with different types of carbohydrates and/or exercise on fat oxidation, carbohydrate oxidation, and energy expenditure over $24 \mathrm{~h}$. A) Changes in fat oxidation over $24 \mathrm{~h}$. B) Changes in carbohydrate oxidation over 24 h. C) Changes in energy expenditure over $24 \mathrm{~h}$. D) Sum of fat oxidation over $24 \mathrm{~h}$. E) Sum of carbohydrate oxidation over $24 \mathrm{~h}$. F) Sum of energy expenditure over $24 \mathrm{~h}$. Data are presented as means \pm SE ( $n=10$ per group). Values in the same row not sharing the same superscript differ significantly $\left({ }^{* / *} \mathrm{P}<0.05,{ }^{* *} \mathrm{P}<0.01,{ }^{* * *} \mathrm{P}<0.001\right)$. 
A) Changes in oxygen uptake during exercise for $1 \mathrm{~h}$

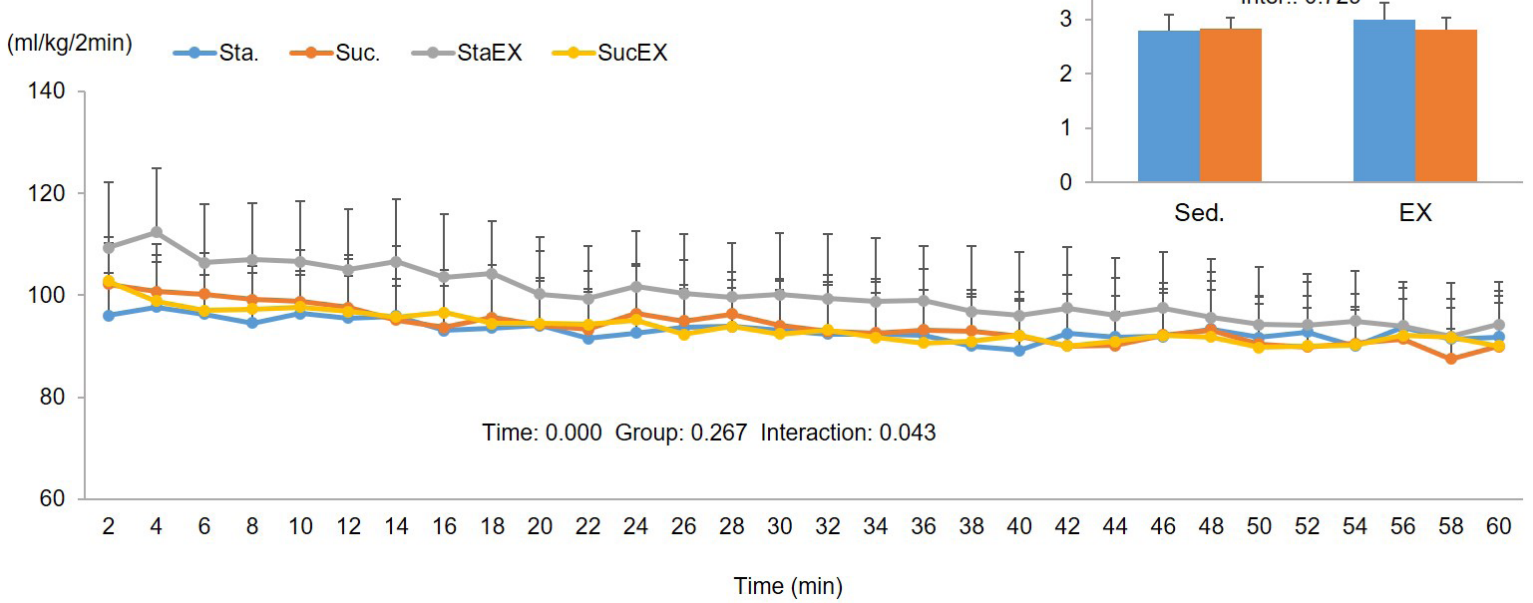

Figure 5. Influence of a high fat diet with different types of carbohydrates and/or exercise on oxygen uptake during exercise. A) Changes in oxygen uptake during exercise for 1 h. B) Sum of oxygen uptake during exercise for 1 h. Data are presented as means \pm SE ( $n=$ 10 per group).

\section{Statistical analysis}

Statistical analyses were performed with SPSS 23.0 for windows (IBM Corp., Armonk, USA). Values are means \pm standard error (SE) of the indicated number of experiments. A two-way analysis of variance (ANOVA) method was applied to determine the interaction and main effect with diet and exercise. A Tukey's post-hoc analysis was conducted if significant interactions or main effects were obtained. A priori, the level of significance was set at 0.05 .

\section{RESULTS}

Changes in body weight and abdominal adipose tissue weight

To clarify the influence of a high fat diet with different types of carbohydrates and/or exercise on basic metabolism in mice, the data of mice at Sta. (HF + Hsta), or Scu. $(\mathrm{HF}+\mathrm{Hscu})$ with/without exercise for 10 weeks were compared. Figure 2 shows the results of body weight and change in epididymal, perirenal, and mesenteric adipose tissue weight. At the onset of the study, there were no differences in body weight between the four groups. Body weight of mice increased progressively throughout the study, but unexpectedly, there were no significant differences in final body weight between the groups (Fig. 2A).

Next, we determined whether diet and exercise changed the weight of abdominal tissues at the end of the experimental period. The weight of epididymal and perirenal adipose tissue were significantly decreased in the exercise groups (epididymal; StaEX, $\mathrm{P}=0.004$ and SucEX, $\mathrm{P}=$ 0.000 Fig. 2C, perirenal; StaEX, $\mathrm{P}=0.004$ and SucEX, $\mathrm{P}$ $=0.000$, Fig. $2 \mathrm{C})$. The weight of mesenteric adipose tissue decreased only in the Sta. diet in the exercise group ( $\mathrm{P}=$ 0.001, Fig. 2D).

\section{Energy metabolism over 24 hours}

The two-way repeated measures ANOVA of the oxygen uptake showed a significant time $(\mathrm{P}=0.000)$ and group $(\mathrm{P}$ $=0.000)$ related effect, but no group-time interaction $(\mathrm{P}=$ 0.627 , Fig. 3A). The sum of the oxygen uptake over $24 \mathrm{~h}$ showed a significant diet effect $(\mathrm{P}=0.000)$. This indicates that oxygen uptake increased in the Suc. diet groups (Suc. $\mathrm{P}=0.000$ and SucEX, $\mathrm{P}=0.002$, Fig. $3 \mathrm{C}$ ).

The two-way repeated measures ANOVA for RER showed a significant time effect $(\mathrm{P}=0.000)$ and a grouptime interaction $(\mathrm{P}=0.000)$, but no group effect $(\mathrm{P}=0.725$, Fig. 3B). Similar to oxygen uptake, we observed significant diet effects on average RER during $24 \mathrm{~h}$. There was a highly significant increase in the average RER in the Suc. diet groups (Suc. $\mathrm{P}=0.000$ and SucEX, $\mathrm{P}=0.000$, Fig. 3D).

The two-way repeated measures ANOVA for fat oxidation showed a significant time $(\mathrm{P}=0.000)$ related effect, but no group effect $(\mathrm{P}=0.071)$ or group-time interaction $(\mathrm{P}=0.619$, Fig. 4A). The sum of the fat oxidation for 24 $\mathrm{h}$, was significantly affected by diet $(\mathrm{P}=0.01)$. The sum of fat oxidation in the Suc. diet without exercise group (Scu. $\mathrm{P}=0.031$ ) was lower than that of the Suc. diet with exercise group $(\mathrm{P}=0.031$ and $\mathrm{P}=0.128$, respectively) (Fig. 4D).

The two-way repeated measures ANOVA for carbohydrate oxidation showed a significant time $(\mathrm{P}=0.000)$ and group related effect $(P=0.000)$, but no group-time interaction ( $\mathrm{P}=0.203$, Fig. 4B). The sum of the carbohydrate oxidation for $24 \mathrm{~h}$, was significantly affected by diet ( $\mathrm{P}$ $=0.000)$ and exercise $(P=0.001)$. The post-hoc analyses showed that the increase in total carbohydrate oxidation was significantly higher in the Suc. diet than in the Sta. $\operatorname{diet}($ Sta. $P=0.000$ and StaEX. $P=0.000$, Fig. 4E).

The two-way repeated measures ANOVA for total energy expenditure showed a significant time $(\mathrm{P}=0.000)$ and group $(\mathrm{P}=0.000)$ related effect, but no group-time interaction ( $\mathrm{P}=0.808$, Fig. $4 \mathrm{C})$. The sum of the energy 
A) Changes in RER during exercise for $1 \mathrm{~h}$

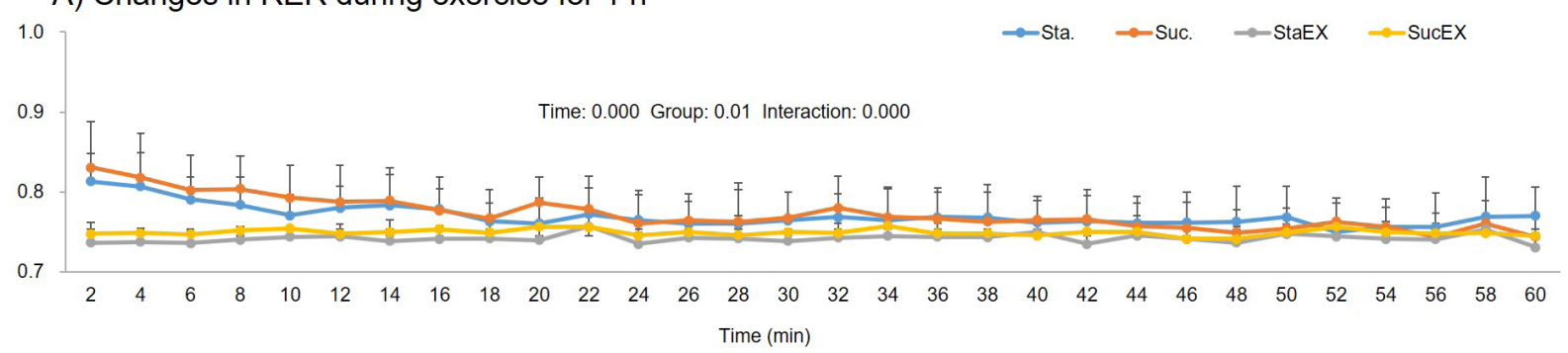

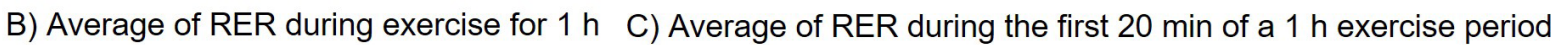
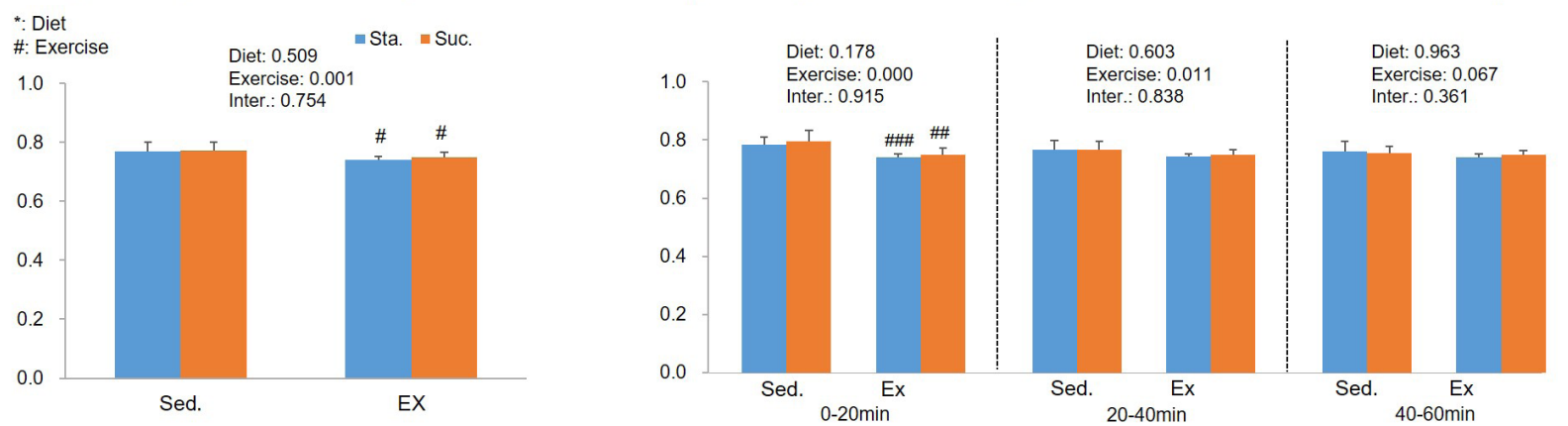

Figure 6. Influence of a high fat diet with different types of carbohydrates and/or exercise on respiratory changes ratio (RER) during exercise. A) Changes in RER during exercise for $1 \mathrm{~h}$. B) Average of RER during exercise for $1 \mathrm{~h}$. C) Average of RER during the first 20 min of a $1 \mathrm{~h}$ exercise period. Data are presented as means \pm SE $(n=10$ per group). Values in the same row not sharing the same superscript differ significantly $\left({ }^{*} P<0.05,{ }^{\prime \prime \prime} P<0.01, \ldots+\cdots P 0.001\right)$.

A) Changes in fat oxidation during exercise for $1 \mathrm{~h}$

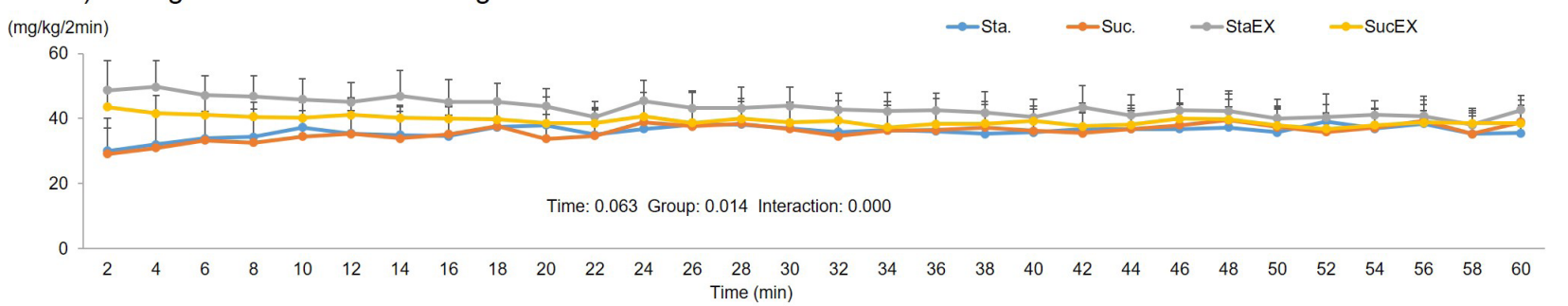

B) Sum of fat oxidation during exercise for $1 \mathrm{~h} \mathrm{C}$ ) Changes in fat oxidation during the first 20 min of a $1 \mathrm{~h}$ exercise period
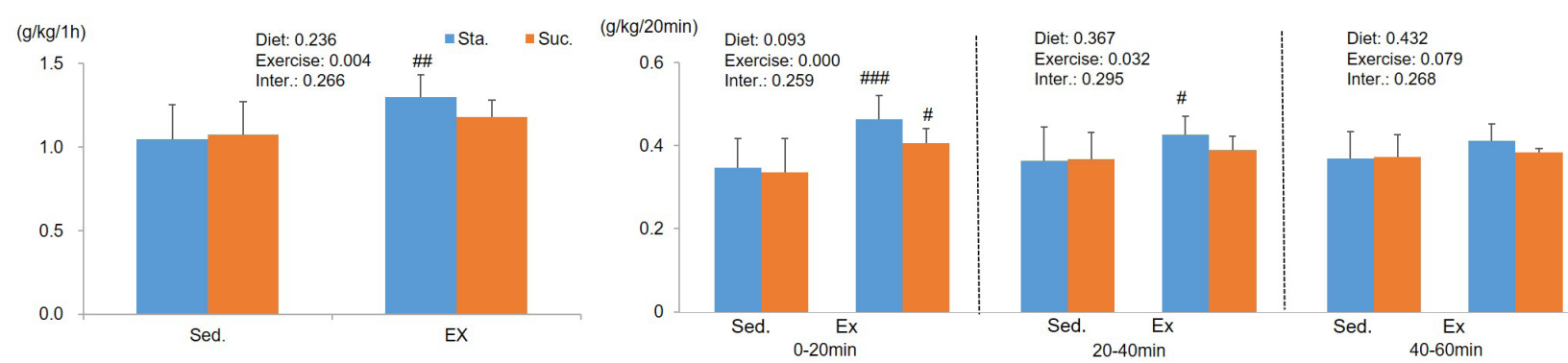

Figure 7. Influence of a high fat diet with different types of carbohydrates and/or exercise on fat oxidation during exercise. A) Changes in fat oxidation during exercise for $1 \mathrm{~h}$. B) Sum of fat oxidation during exercise for $1 \mathrm{~h}$. C) Changes in fat oxidation during the first 20 min of a $1 \mathrm{~h}$ exercise period. Data are presented as means \pm SE $(n=10$ per group). Values in the same row not sharing the same superscript differ significantly $\left({ }^{\#} \mathrm{P}<0.05,{ }^{\text {"\#m }} \mathrm{P}<0.01,{ }^{\prime \prime \prime \prime} \mathrm{P}<0.001\right)$. 


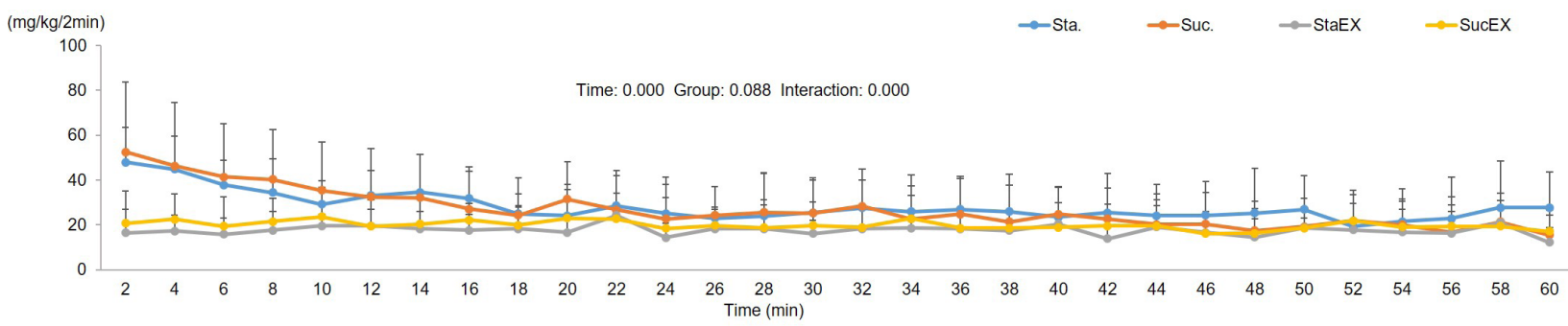

B) Sum of carbohydrate oxidation during exercise for $1 \mathrm{~h}$

C) Changes in carbohydrate during the first 20 min period
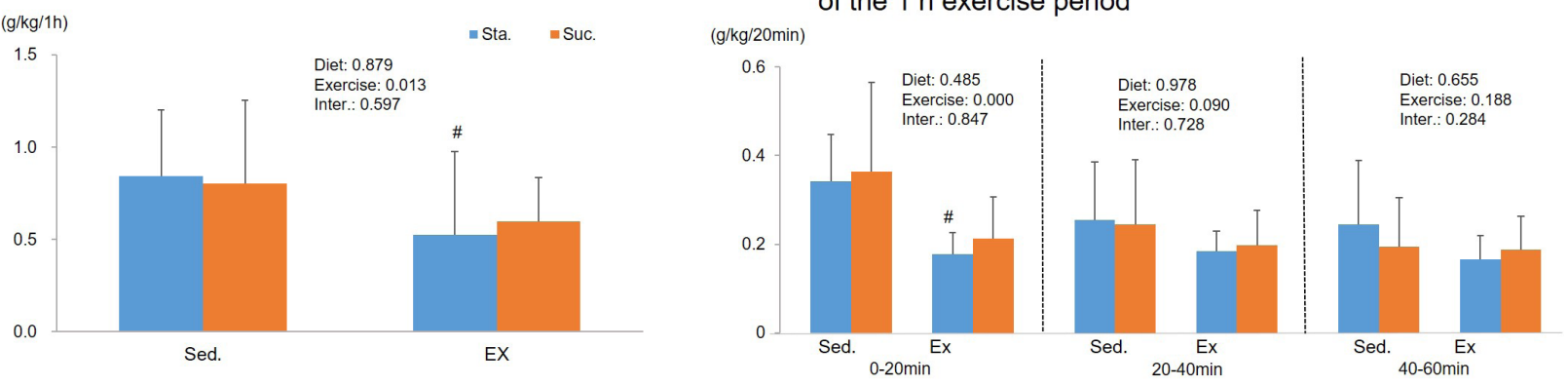

Figure 8. Influence of a high fat diet with different types of carbohydrates and/or exercise on carbohydrate oxidation during exercise. A) Changes in carbohydrate oxidation during exercise for $1 \mathrm{~h}$. B) Sum of carbohydrate oxidation during exercise for $1 \mathrm{~h}$. C) Changes in carbohydrate during the first 20 min period of the $1 \mathrm{~h}$ exercise period. Data are presented as means $\pm S E(n=10$ per group). ( $(P<0.05)$

A) Changes in energy expenditure during exercise for $1 \mathrm{~h}$

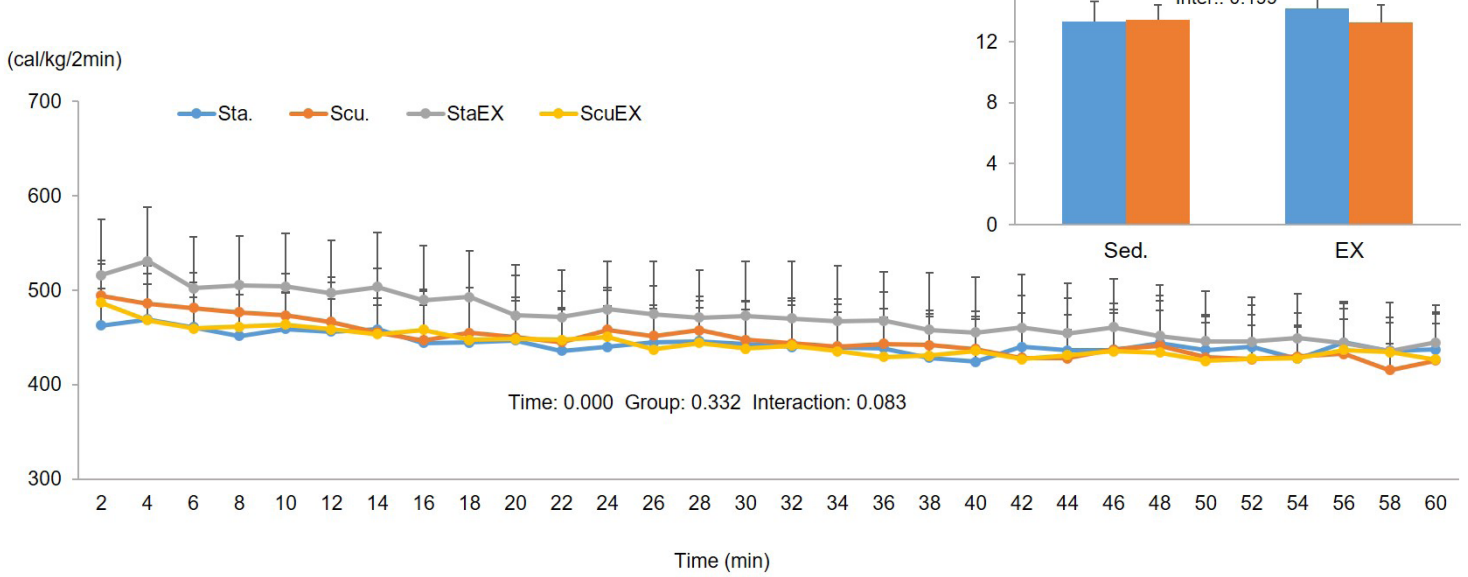

Figure 9. Influence of a high fat diet with different types of carbohydrates and/or exercise on total energy expenditure during exercise. A) Changes in energy expenditure during exercise for $1 \mathrm{~h}$. B) Sum of energy expenditure during exercise for $1 \mathrm{~h}$. Data are presented as means \pm SE $(n=10$ per group).

expenditure for $24 \mathrm{~h}$ was significantly affected by diet $(\mathrm{P}$ $=0.000)$ and exercise $(\mathrm{P}=0.008)$. Total energy expenditure was higher in the Suc. diet (Sta. vs. Scu. $\mathrm{P}=0.002$ and StaEX. Vs. ScuEx. P=0.003), and the Suc. diet with exercise group had significantly higher energy expenditure than that of the Suc. diet without exercise group $(\mathrm{P}=0.032$ Fig. 4F).

\section{Energy metabolism during exercise}

The two-way repeated measures ANOVA for oxygen uptake during a $1 \mathrm{~h}$ exercise period showed a significant time effect $(\mathrm{P}=0.000)$ and a group-time interaction $(\mathrm{P}=0.043)$, but no significant group effect $(\mathrm{P}=0.267$, Fig. $5 \mathrm{~A})$. The sum of oxygen uptake during $1 \mathrm{~h}$ of exercise was not affected by diet composition ( $\mathrm{P}=0.136)$ and exercise $(\mathrm{P}=0.084)$. There were no differences among the groups (Fig. 5B).

The two-way repeated measures ANOVA for RER during $1 \mathrm{~h}$ of exercise showed significant time $(\mathrm{P}=0.000)$ and group effects $(\mathrm{P}=0.01)$ and a group-time interaction $(\mathrm{P}=0.000$, Fig. 6A). In the average of RER during $1 \mathrm{~h}$ of exercise, we observed a significant exercise effect $(\mathrm{P}=$ 0.001 , Fig. 6B). The average RER was lower in exercise groups (StaEx. $\mathrm{P}=0.032$ and ScuEx. $\mathrm{P}=0.027$ ). In addition, we analyzed this again, measuring every $20 \mathrm{~min}$, and 
found that exercise training decreased RER during $1 \mathrm{~h}$ of exercise in the first $20 \mathrm{~min}$, regardless of diet composition (StaEX. $\mathrm{P}=0.000$ and ScuEx, $\mathrm{P}=0.002$, Fig. 6C).

The two-way repeated measures ANOVA for fat oxidation during $1 \mathrm{~h}$ of exercise showed a significant group effect $(\mathrm{P}=0.014)$ and a group-time interaction $(\mathrm{P}=0.000)$, but no time effect $(\mathrm{P}=0.063$, Fig. 7A). Similar to RER, only exercise had an effect on fat oxidation $(\mathrm{P}=0.004)$. The sum of fat oxidation increased in the Sta. with exercise group (StaEX. $\mathrm{P}=0.004$, ScuEX. $\mathrm{P}=0.164$, Fig. 7B). However, when the $1 \mathrm{~h}$ exercise period was split into $20 \mathrm{~min}$ intervals, the results showed that, during the first $20 \mathrm{~min}$, training increased fat oxidation regardless of diet (StaEX. P = 0.000, ScuEX. P = 0.037). However, the exercise effect was valid for up to 40 min only in the Sta. with exercise group $(\mathrm{P}=0.025$, Fig. 7C).

The two-way repeated measures ANOVA for carbohydrate oxidation during $1 \mathrm{~h}$ of exercise showed a significant time effect $(\mathrm{P}=0.000)$ and a group-time interaction ( $\mathrm{P}$ $=0.000)$, but no group effect $(\mathrm{P}=0.088$, Fig. $8 \mathrm{~A})$. The sum of carbohydrate oxidation during $1 \mathrm{~h}$ of exercise was significantly affected by exercise $(\mathrm{P}=0.013)$. The posthoc analyses showed that total carbohydrate oxidation increased significantly in the Sta. diet with exercise group $(\mathrm{P}=0.043$, Fig. $8 \mathrm{~B})$ and this occurs in the first $20 \mathrm{~min}$ of exercise $(\mathrm{P}=0.031$, Fig. $8 \mathrm{C})$.

The two-way repeated measures ANOVA for energy expenditure showed only a significant time effect $(\mathrm{P}=0.000)$, there were no group effects $(\mathrm{P}=0.332)$ or a group-time interaction ( $\mathrm{P}=0.083$, Fig. 9A). Moreover, the sum of energy expenditure during $1 \mathrm{~h}$ of exercise was not affected by diet composition $(\mathrm{P}=0.339)$ or exercise $(\mathrm{P}=0.354)$. There was no difference among the groups (Fig. 9B).

\section{DISCUSSION}

Along with the adaptation to a Western lifestyle over the past decades, the dietary patterns of Korean children and adolescents have been gradually changing. A Western lifestyle includes not only a diet rich in lipids and sugar, but also physical inactivity. Although there is strong evidence that the amount and type of fat in the diet can have strong effects on metabolism, the type of carbohydrates influencing metabolic responses in a diet is also of great interest. Hence, the long-term goal of this study was to understand the relationship between type of carbohydrates, weight, and energy metabolism, and to prevent childhood obesity and related diseases. To achieve this, we used an open circuit calorimetry system to investigate the influence of a high fat diet with different types of carbohydrates (sucrose or starch) with/without exercise on energy metabolism at rest and during $1 \mathrm{~h}$ of exercise in mice.

Our results showed that high sucrose did not cause greater obesity than starch. Unexpectedly, there were no significant differences between the groups in the final body weights. It is consistent with a previous study by Sakamoto et al., (2012) that demonstrated no change in body weight following similar, prolonged periods of high sucrose feeding ${ }^{29}$. A previous study on energy balance by Dulloo et al. (1985) indicated that differences in energy balance between sucrose and starch are small ${ }^{30}$. Indeed, several reviews suggest that there is no evidence that an ad libitum diet with sucrose causes more weight gain than a diet with starch when total carbohydrate intake is the same $^{31,32}$. On the other hand, some studies showed weight gain $^{7,33}$ and an overall systematic review suggested a positive influence of starch on weight loss ${ }^{34}$. However, it is not clear what caused the differences between these two types of diets. Only a few studies have directly compared the effect of dietary intake of sucrose and starch on energy metabolism. According to the results of the study by Maekawaa et al., (2017), high sucrose-fed mice displayed decreased body weight compared with mice on a diet of normal chow or high starch after 14 weeks of feeding ${ }^{35}$. They explained that this was due to increased energy expenditure. In addition, Raben et al. (1997) compared the effect of an ad libitum high sucrose, high starch, and high fat diet in lean or post-obese women on energy expenditure $^{36}$. After 14 days, the $24 \mathrm{~h}$ energy expenditure was significantly increased on the sucrose diet compared with that of the other diets.

We then investigated the effect of the sucrose diet on energy metabolism using indirect calorimetry to compare each mouse after 10 weeks of experimental treatment. As expected, mice on a high fat-high sucrose diet consistently displayed a higher oxygen uptake and RER, indicating an increase in carbohydrate oxidation at rest compared with that of the Sta. diet. This implies both an initial switch to carbohydrates as the major energy source and continued adaptation to further increase carbohydrate use. However, in contrast to the results of the present study, Burchfield et al. (2018) showed that RER and oxygen uptake of mice on a high fat-high sucrose diet decreased with increasing time on the $\operatorname{diet}^{37}$.

Fat oxidation in the Scu. diet was lower than that in the Sta. diet. However, there were no differences between the Suc. diet with exercise and the Sta. diet groups. This indicates that exercise helps to maintain the fat oxidation capacity in the Scu. diet. Although the differences did not result in significant weight reduction, total energy expenditure was increased in the Suc. diet with or without exercise. Small differences of just a few kcal/day can lead to substantial differences in body weight in the long term. Taken together, our findings indicate that energy metabolism over $24 \mathrm{~h}$ was more influenced by diet than by exercise.

The expression of some genes controlling energy homeostasis are regulated by epigenetic mechanisms that may play a role in body weight regulation. It is well recognized that sucrose stimulates the sympathetic nervous system and leads to an increase in brown adipose tissue (BAT) activity and mass ${ }^{7,38,39}$. However, the pathway by which sucrose affects BAT activity and the effects of a chronic high sucrose diet on BAT, which plays an important role in energy expenditure, are not well understood. In addi- 
tion, body weight and glucose metabolism is regulated by various hormones such as glucagon-like peptide 1 (GLP-1) and fibroblast growth factor 21 (FGF21), which contribute to the reduction in body weight by increasing energy expenditure ${ }^{35,40,41}$. However, the expression and action of GLP-1 and FGF21 in mice chronically fed a high fathigh sucrose diet have not been fully investigated ${ }^{35}$. Thus, further studies are required to confirm the optimal amount and type of dietary carbohydrates for energy metabolism.

During $1 \mathrm{~h}$ of exercise, we did not find any changes in oxygen uptake and energy expenditure in any of the experimental groups. In agreement with our results, most previous studies ${ }^{42-44}$ have not found an effect of diet composition on total energy expenditure if energy intake was fixed. However, exercise had a significant effect on RER, fat oxidation, and carbohydrate oxidation. The average RER was lower in exercise groups; in particular, we found that the initial 20 min RER phase during the $1 \mathrm{~h}$ exercise period was significantly lower in exercised groups regardless of diet composition. Substrate utilization is largely driven by the availability of substrate. Excess carbohydrate intake promotes its own oxidation by stimulating the cellular uptake and oxidation of glucose during exercise, while decreasing the fat availability and oxidation ${ }^{45}$. Exercise, however, had a positive effect on fat oxidation during the $1 \mathrm{~h}$ exercise period. This effect was seen for up to 40 min in the Sta. diet group. Taken together, these results indicate that energy metabolism during exercise was more influenced by exercise than diet. In our experiments, mice were made to exercise for approximately $70-75 \%$ of maximum oxygen uptake. However, high intensity exercise can also mediate stress related hormones, such as glucocorticoids, cortisol, and catecholamine ${ }^{13}$ that trigger the release of glucose stored as glycogen into the bloodstream, leading to high blood sugar levels, an insulin response, and therefore, metabolic diseases ${ }^{46}$.

A limitation of this study is that the above results alone cannot prove that sucrose is not harmful. The greatest difference between sucrose and starch is probably the blood glucose and insulin response, and there may also be differences in some genes controlling energy homeostasis. Hence, future research should focus on the influence of high fat diets with different types of carbohydrates and/ or exercise on more functional aspects, including glucose, insulin in blood, and UCP1, PGC1a, GLP-1, and FGF21 in the adipose tissue.

Our results showed that high sucrose did not cause greater obesity than starch. The weight of adipose tissue decreased markedly in exercise groups. Dietary sucrose increased energy expenditure during a $24 \mathrm{~h}$ period by increasing carbohydrate oxidation. Long-term exercise training increased fat oxidation during $1 \mathrm{~h}$ of exercise, regardless of diet. On the basis of these results, our study demonstrates that: (a) the type of carbohydrates included in the diet influence the metabolic responses for $24 \mathrm{~h}$, (b) training had a larger effect on energy metabolism than diet during $1 \mathrm{~h}$ of exercise, (c) both abdominal adipose tissue weight and fat oxidation during exercise for $1 \mathrm{~h}$ showed the beneficial effects of moderate physical activity on weight maintenance.

\section{ACKNOWLEDGMENTS}

This work was supported by the Ministry of Education of the Republic of Korea and the National Research Foundation of Korea (NRF-2016S1A5B5A07918098). The authors declare that they have no competing interests.

\section{REFERENCES}

1. Cordain L, Eaton SB, Sebastian A, Mann N, Lindeberg S, Watkins BA, O'Keefe JH, Brand-Miller J. Origins and evolution of the Western diet: health implications for the 21st century. Am J Clin Nutr. 2005;81:341-54.

2. Ministry of Culture, Sports and Tourism. Survey on national leisure activities 2016-2018. MCST. 2019.

3. Popkin BM. Nutrition transition and the global diabetes epidemic. Curr Diab Rep. 2015;15:64.

4. Schwartz RS, Ravussin E, Massari M, O'Connell M, Robbins DC. The thermic effect of carbohydrate versus fat feeding in man. Metabolism. 1985;34:285-93.

5. Hermsdorff HH, Volp AC, Bressan J. Macronutrient profile affects diet-induced thermogenesis and energy intake. Arch Latinoam Nutr. 2007;57:33-42.

6. Flatt JP. Dietary fat, carbohydrate balance, and weight maintenance: effects of exercise. Am J Clin Nutr. 1987;45:296306.

7. Kanarek RB, Orthen-Gambill N. Differential effects of sucrose, fructose and glucose on carbohydrate-induced obesity in rats. J Nutr. 1982;112:1546-54.

8. Granneman JG, Wade GN. Effect of sucrose overfeeding on brown adipose tissue lipogenesis and lipoprotein lipase activity in rats. Metabolism. 1983;32:202-7.

9. Bukowiecki LJ, Lupien J, Folléa N, Jahjah L. Effects of sucrose, caffeine, and cola beverages on obesity, cold resistance, and adipose tissue cellularity. Am J Physiol. 1983;244:R500-7.

10. Giusti $V$, Schneiter $P$, Thiébaud $D$, Landry $M$, Burckhardt $P$, Jéquier E, Tappy L. Influences of body weight, body composition, and substrate oxidation rate on resting postabsorptive glucose production and gluconeogenesis. Int J Obes Relat Metab Disord. 1996;20:842-7.

11. Aller EE, Abete I, Astrup A, Martinez JA, van Baak MA. Starches, Sugars and Obesity. Nutrients. 2011;3:341-69.

12. Foster-Powell K, Holt SH, Brand-Miller JC. International table of glycemic index and glycemic load values: 2002. Am J Clin Nutr. 2002;76:5-56.

13. Gyllenhammer LE, Weigensberg MJ, Spruijt-Metz D, Allayee H, Goran MI, Davis JN. Modifying Influence of Dietary Sugar in the Relationship Between Cortisol and Visceral Adipose Tissue in Minority Youth. Obesity (Silver Spring). 2014;22:474-81.

14. Jenkins AL, Morgan LM, Bishop J, Jovanovski E, Vuksan V. Randomized Clinical Trialin Healthy Individualson the Effect 
of Viscous Fiber Blend on Glucose Tolerance When Incorporated in Capsules or into the Carbohydrate or Fat Component of the Meal. J Am Coll Nutr. 2014;33:400-5.

15. Kondo K, Ishikado A, Morino K, Nishio Y, Ugi S, Kajiwara S, Kurihara M, Iwakawa H, Nakao K, Uesaki S, Shigeta Y, Imanaka $\mathrm{H}$, Yoshizaki T, Sekine O, Makino T, Maegawa $\mathrm{H}$, King GL, Kashiwagi A. A high-fiber, low-fat diet improves period on disease markers in high-risk subjects: apilotstudy. Nutr Res. 2014;34:491-8.

16. Breneman $\mathrm{CB}$, Tucker $\mathrm{L}$. Dietary fibre consumption and insulin resistance -the role of body fat and physical activity. $\mathrm{Br} J$ Nutr. 2013;110:75-83.

17. Storlien LH, Higgins JA, Thomas TC, Brown MA, Wang HQ, Huang XF, Else PL. Diet composition and insulin action in animal models. Br J Nutr. 2000;83:S85-90.

18. Alharbi M, Gallagher R, Kirkness A, Sibbritt D, Tofler G. Longterm outcomes from Healthy Eating and Exercise Lifestyle Program for overweight people with heart disease and diabetes. Eur J Cardiovasc Nurs. 2016;15:91-9.

19. Fofonka A, Ribeiro JP, Casali KR, Schaan BD. Effects of vildagliptin compared with glibenclamide on glucose variability after a submaximal exercise test in patients with type 2 diabetes: study protocol for a randomized controlled trial. Trials. 2014;15:424.

20. Inouye J, Matsuura C, Li D, Castro R, Leake A. Lifestyle intervention for filipino americans at risk for diabetes. J Community Health Nurs. 2014;31:225-37.

21. Kim J, Hwang H, Park J, Yun HY, Suh H, Lim K. Silk peptide treatment can improve the exercise performance of mice. $J$ Int Soc Sports Nutr. 2014;11:35.

22. Kim J, Park J, Kim B, Lee CH, Lim K, Suh H. Effects of Different doses of Silk Peptide on Energy Metabolism During Exercise in Mice. J Exerc Nutrition Biochem. 2017;21:21-5.

23. Kim J, Hwang H, Yun HY, Kim B, Lee CH, Suh H, Lim K. Silk peptide intake increases fat oxidation at rest in exercised mice. J Nutr Sci Vitamino (Tokyo)l. 2013;59:250-5.

24. Hwang $\mathrm{H}$, Kim J, Park J, Yun H, Cheon WK, Kim B, Lee $\mathrm{CH}$, Suh $\mathrm{H}$, Lim K. Red ginseng treatment for two weeks promotes fat metabolism during exercise in mice. Nutrients. 2014;6:1874-85.

25. Kim J, Jeon Y, Hwang H, Suh H, Lim K. Effects of oral caffeine and capsaicin administration on energy expenditure and energy substrates utilization in resting rats. J Exerc Nutr Biochem. 2011;15:183-9.

26. Lim K, Kim J, Jeon Y, Hwang H, Suh H. Measurement of resting metabolic rate using metabolic chamber in resting rats. $J$ Exerc Nutr Biochem. 2011;15:35-40.

27. Kim J, Park J, Kim B, Lee CH, Lim K, Suh H. Effects of Silk Peptides Administration on Fat Utilization Over a Whole Day in Mice. J Exerc Nutr Biochem. 2016;20:53-9.

28. Jeon YR, Kim JS, Hwang HJ, Lim KW. Effects of endurance training for 4 weeks on resting metabolic rate and excess post-exercise oxygen consumption in mouse. J Exerc Nutr Biochem. 2012;16:113-22.

29. Sakamoto E, Seino Y, Fukami A, Mizutani N, Tsunekawa S, Ishikawa $\mathrm{K}$, Ogata $\mathrm{H}$, Uenishi E, Kamiya $\mathrm{H}$, Hamada $\mathrm{Y}$, Sato H, Harada N, Toyoda Y, Miwa I, Nakamura J, Inagaki N, Oiso Y, Ozaki N. Ingestion of a moderate high-sucrose diet results in glucose intolerance with reduced liver glucokinase activity and impaired glucagon-like peptide-1 secretion. J Diabetes Investig. 2012;3:432-40.

30. Dulloo AG, Eisa OA, Miller DS, Yudkin J. A comparative study of the effects of white sugar, unrefined sugar and starch on the efficiency of food utilization and thermogenesis. Am J Clin Nutr. 1985;42:214-19.

31. Arola L, Bonet ML, Delzenne N, Duggal MS, Gómez-Candela $C$, Huyghebaert $A$, Laville $M$, Lingström $P$, Livingstone $B$, Palou A, Picó C, Sanders T, Schaafsma G, van Baak M, van Loveren $C$, van Schothorst EM. Summary and general conclusions/outcomes on the role and fate of sugars in human nutrition and health. Obes Rev. 2009;10:55-8.

32. Van Baak MA, Astrup A. Consumption of sugars and body weight. Obes Rev. 2009;10:9-23.

33. Kanarek RB, Aprille JR, Hirsch E, Gualtiere L, Brown CA. Sucrose-induced obesity: effect of diet on obesity and brown adipose tissue. Am J Physiol. 1987;253:R158-66.

34. Thomas DE, Elliott EJ, Baur L. Low glycaemic index or low glycaemic load diets for overweight and obesity. Cochrane Database Syst Rev. 2007;18:CD005105.

35. Maekawa R, Seino Y, Ogata H, Murase M, lida A, Hosokawa $\mathrm{K}$, Joo E, Harada N, Tsunekawa S, Hamada Y, Oiso Y, Inagaki N, Hayashi Y, Arima H. Chronic high-sucrose diet increases fibroblast growth factor 21 production and energy expenditure in mice. J Nutr Biochem. 2017;49:71-9.

36. Raben A, Macdonald I, Astrup A. Replacement of dietary fat by sucrose or starch: effects on $14 \mathrm{~d}$ ad libitum energy intake, energy expenditure and body weight in formerly obese and never-obese subjects. Int J Obes Relat Metab Disord. 1997;21:846-59.

37. Burchfield JG, Kebede MA, Meoli CC, Stöckli J, Whitworth PT, Wright AL, Hoffman NJ, Minard AY, Ma X, Krycer JR, Nelson ME, Tan SX, Yau B, Thomas KC, Wee NKY, Khor EC, Enriquez RF, Vissel B, Biden TJ, Baldock PA, Hoehn KL, Cantley J, Cooney GJ, James DE, Fazakerley DJ. High dietary fat and sucrose results in an extensive and time-dependent deterioration in health of multiple physiological systems in mice. J Biol Chem. 2018;293:5731-45.

38. Granneman JG, Wade GN. Effect of sucrose overfeeding on brown adipose tissue lipogenesis and lipoprotein lipase activity in rats. Metabolism. 1983;32:202-7.

39. Bukowiecki LJ, Lupien J, Folléa N, Jahjah L. Effects of sucrose, caffeine, and cola beverages on obesity, cold resistance, and adipose tissue cellularity. Am J Physiol. 1983;244:R500-7.

40. Lockie SH, Heppner KM, Chaudhary N, Chabenne JR, Morgan DA, Veyrat-Durebex C, Ananthakrishnan G, Rohner-Jeanrenaud F, Drucker DJ, DiMarchi R, Rahmouni K, Oldfield BJ, Tschöp MH, Perez-Tilve D. Direct control of brown adipose tissue thermogenesis by central nervous system glucagon-like peptide-1 receptor signaling. Diabetes. 2012;61:2753-62.

41. Beiroa D, Imbernon M, Gallego R, Senra A, Herranz D, Villarroya F, Serrano M, Fernø J, Salvador J, Escalada J, Dieguez C, Lopez M, Frühbeck G, Nogueiras R. GLP-1 agonism stimulates brown adipose tissue thermogenesis and browning through hypothalamic AMPK. Diabetes. 2014;63:3346-58. 
42. Abbott WGH, Howard BV, Ruotolo G, Ravussin E. Energy expenditure in humans: effects of dietary fat and carbohydrate. Am J Physiol. 1990;258:E347-51.

43. Hurni M, Burnand B, Pittet PH, Jequier E. Metabolic effects of a mixed and a high-carbohydrate low-fat diet in man, measured over $24 \mathrm{~h}$ in a respiration chamber. $\mathrm{Br} \mathrm{J}$ Nutr. 1982;47:33-43.

44. Schrauwen P, van Marken Lichtenbelt WD, Saris WH, Westerterp KR. Changes in fat oxidation in response to a high-fat diet. Am J Clin Nutr. 1997;66:276-82.

45. Blaak EE, Saris WHM. Health aspects of various digestible carbohydrates. Nutr Res. 1995;15:1547-73.

46. Laville M, Nazare JA. Diabetes, insulin resistance and sugars. Obes Rev. 2009;10:24-33. 